\title{
A new species of Stenocercus (Squamata, Iguania) from central-western Brazil with a key to Brazilian Stenocercus
}

\author{
Omar Torres-Carvajal \\ Natural History Museum and Biodiversity Research Center, and Department of Ecology and Evolutionary Biology, Dyche \\ Hall, 1345 Jayhawk Boulevard, The University of Kansas, Lawrence, KS 66045-7561, USA. E-mail: otorres@ku.edu.
}

\begin{abstract}
A new species of Stenocercus (Squamata, Iguania) from central-western Brazil with a key to Brazilian Stenocercus. A new species of Stenocercus from centralwestern Brazil differs from other Stenocercus by the following combination of characters: head and body scales strongly keeled, posthumeral and postfemoral mite pockets absent, nostrils laterally oriented, supraciliary scales not enlarged or projected, and caudal fracture planes absent. Morphologically, the new species more closely resembles $S$. prionotus and $S$. caducus. The latter species has been reported in Brazil based on misidentified specimens from Mato Grosso that correspond to the new species described herein. However, it is very likely that $S$. caducus occurs in Brazil because it has been reported from geographically close areas. Therefore, I recognize seven species of Stenocercus from Brazil and provide a dichotomous key to assist in the identification of specimens.
\end{abstract}

Keywords: Squamata, Iguania, Stenocercus sinesaccus sp. nov., central-western Brazil.

\section{Introduction}

The neotropical lizard genus Stenocercus Duméril and Bibron (1837) includes more than 50 species that occur mostly in the Andes and adjacent lowland areas from northern Colombia and Venezuela to central Argentina. More than half of the species of Stenocercus (Iguanidae of Macey et al. 1997, Tropiduridae of Frost et al. 2001, Tropidurinae/Tropidurini of Schulte et al. 2003) occur in Peru, where many new species

Received 25 April 2005.

Accepted 7 November 2005.

Distributed December 2005. continue to be discovered (Fritts 1972, Cadle 1991, 1998, 2001, Lehr 2002, Torres-Carvajal 2005a, b). In contrast, only seven species have been recorded for Brazil. Ávila-Pires (1995) reported $S$. dumerilii, $S$. fimbriatus, and $S$. roseiventris for Brazilian Amazonia; however, Ávila-Pires (1995) reported S. roseiventris for Acre based only on the account provided by R. Etheridge in Peters and Donoso-Barros (1970), which does not list voucher specimens. I confirm the presence of $S$. roseiventris in Brazil based on specimen MCZ 133219 collected in the upper valley of Purus river, Acre. Two additional species were reported from southern Brazil - S. azureus and S. pectinatus (Peters and 
Donoso-Barros 1970, Cei 1993) - although no verified records of $S$. pectinatus from this area are available (Avila 1999). Stenocercus tricristatus was described from Brazil without specific locality data (Duméril 1851), but it is possible that this species occurs in Minas Gerais (Ávila-Pires 1995). Finally, S. caducus has been reported repeatedly from Mato Grosso (Cope 1887, Boulenger 1903, Peters and Donoso-Barros 1970, Cei 1993) based on misidentified specimens that correspond to a new species described herein.

\section{Materials and Methods}

This description is based upon examination of four specimens deposited in the herpetological collections of the Academy of Natural Sciences of Philadelphia (ANSP), British Museum of Natural History in London (BMNH) and Museum of Comparative Zoology in Cambridge (MCZ). Specimens of other species of Stenocercus examined in this study are listed in Appendix I. Snout-vent length (SVL) and tail length (TL) measurements were taken with a ruler and recorded to the nearest millimeter. All other measurements were made with digital calipers and recorded to the nearest $0.1 \mathrm{~mm}$. Sex was determined by noting the presence of hemipenes. X-ray radiographs were taken with a FTI Corporation Unit at $5 \mathrm{~mA}$ and $50 \mathrm{kV}$ for 40-50 s using Kodak's Industrex SR-1 film. I followed the terminology of Cadle (1991) and Torres-Carvajal $(2000,2004)$ for characters included in the description.

\section{Stenocercus sinesaccus sp. nov.}

Stenocercus caducus; Cope, 1887:55; Peters and Donoso-Barros (part), 1970:213; Cei (part), 1993:302.

Holotype - BMNH 1903.3.26.7, an adult male, from Chapada [Chapada dos Guimarães, $15^{\circ} 26^{\prime} \mathrm{S}, 55^{\circ} 45^{\prime} \mathrm{W}, 690 \mathrm{~m}$ ], Mato Grosso, Brazil, collected by M. A. Robert.

Paratopotypes - ANSP 12947 (adult male), 12948 (adult female), collected by H. H. Smith;
MCZ 171198 (formerly BMNH 1903.3.26.9, adult male), same data as holotype.

Diagnosis - Stenocercus sinesaccus (Figure 1) differs from all other species of Stenocercus except S. caducus, S. dumerilii, S. prionotus, and $S$. tricristatus in having strongly keeled and mucronate body scales, laterally oriented nostrils, and in lacking a postfemoral mite pocket. It differs from $S$. caducus and $S$. prionotus in lacking a posthumeral mite pocket; the latter two species have a deep posthumeral mite pocket covered by an axillary flap (Figure 2; Cadle 2001). In addition, Stenocercus sinesaccus lacks caudal fracture planes, a condition only shared by $S$. dumerilii, S. scapularis, and S. tricristatus. The new species differs from $S$. dumerilii and $S$. tricristatus in lacking enlarged post-supraciliaries (Ávila-Pires 1995); S. scapularis differs from $S$. sinesaccus in having a distinct postfemoral mite pocket and projected supraciliaries.

Characterization - (1) Maximum total length in males $257 \mathrm{~mm}(\mathrm{~N}=3)$; (2) maximum total length in females $272 \mathrm{~mm}(\mathrm{~N}=1)$; (3) vertebrals 28-30; (4) paravertebrals 32-34; (5) scales around midbody 31-34; (6) supraoculars 4; (7) internasals 6; (8) postrostrals 4-5; (9) loreals 3; (10) gulars 12-14; (11) lamellae on Finger IV 13-16; (12) lamellae on Toe IV 23-25; (13) posthumeral pocket absent; (14) postfemoral pocket absent; (15) parietal eye visible; (16) occipital scales large, imbricate, strongly keeled; (17) one enlarged, non-projected angulate temporal; (18) row of enlarged supraoculars absent; (19) scales on frontonasal region imbricate; (20) preauricular fringe absent; (21) neck folds absent; (22) lateral and dorsal nuchals similar in size; (23) posterior gulars in adults keeled, imbricate, mucronate, not notched; (24) lateral and dorsal body scales similar in size; (25) vertebral crest prominent; (26) dorsolateral crest present; (27) ventrals in adults keeled, imbricate, mucronate; (28) scales on posterior surfaces of thighs keeled, imbricate, mucronate; (29) prefemoral fold absent; (30) 

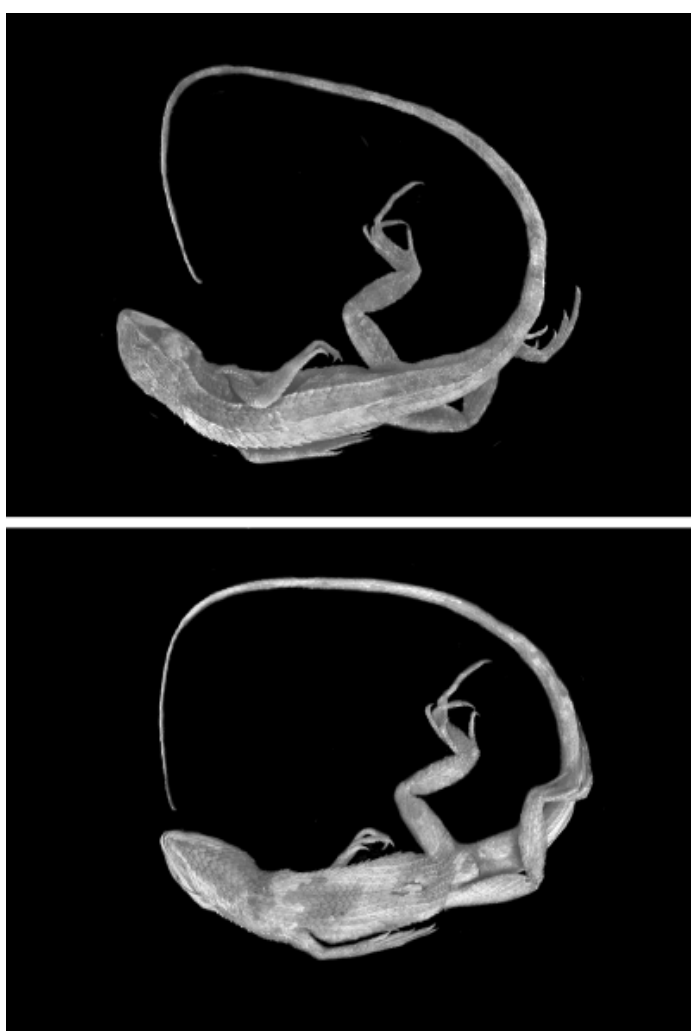

Figure 1 - Dorsal (top) and ventral (bottom) views of Stenocercus sinesaccus sp. nov. Holotype, BMNH 1903.3.26.7, male, 73 mm SVL.
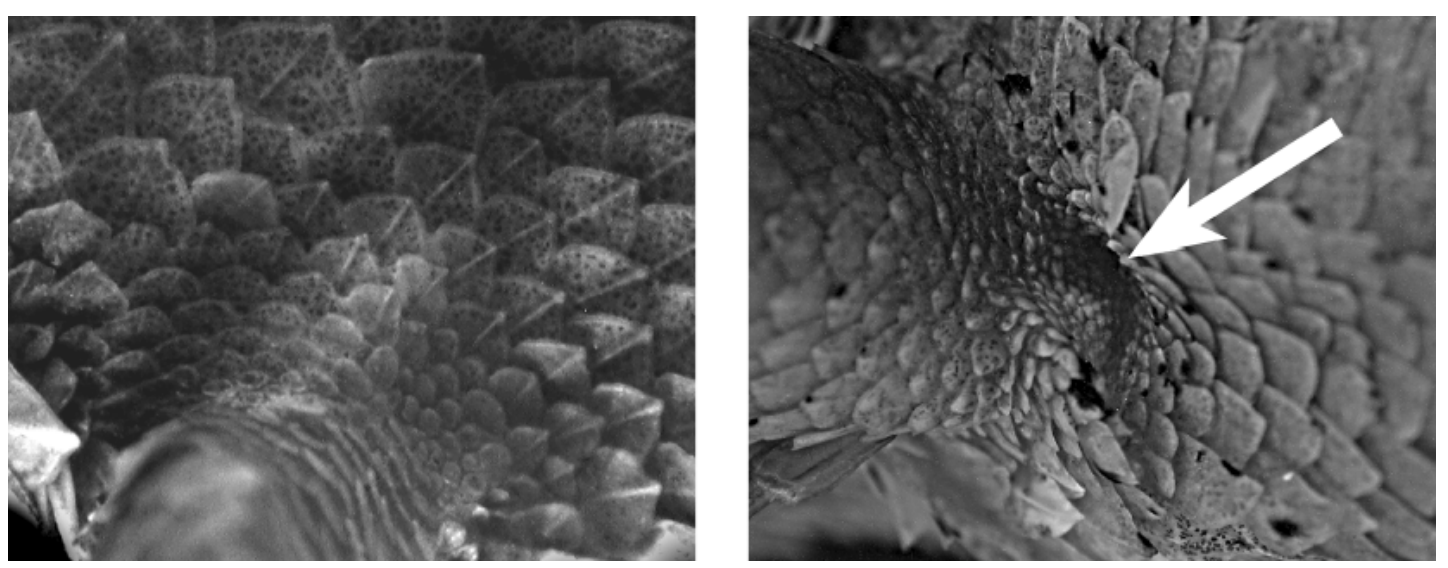

Figure 2 - Left axillae of Stenocercus sinesaccus sp. nov. (left, holotype, BMNH 1903.3.26.7) and Stenocercus caducus (right, UTA 38046) in lateral view. Posthumeral mite pocket in S. caducus is indicated by white arrow.

inguinal groove absent; (31) preanals projected; (32) tail not strongly compressed laterally in adult males; (33) tail length $72-73 \%$ of total length; (34) caudal fracture planes absent; (35) caudals not spinose; (36) dark stripe extending anterodorsally from subocular region to supraciliaries in males; (37) gular region of adult females cream; (38) gular region of adult males cream; (39) black blotch on ventral surface of neck in adult males absent; (40) thin black or dark brown midventral line absent; (41) black patch on ventral surface of thighs absent; (42) background color of dorsum in males brown in preservative; (43) postxiphisternal inscriptional ribs in contact medially (Pattern 6A of TorresCarvajal 2004). Sexual variation in measurements and scale counts are presented in Table 1.

Description of holotype - Male (Figures 1 and 3); $\mathrm{SVL}=73 \mathrm{~mm}$; TL = $184 \mathrm{~mm}$; maximum head width $=12.5 \mathrm{~mm}$; head length $=17.4 \mathrm{~mm}$; head height $=10.5 \mathrm{~mm}$; occipitals, parietals, interparietal, and postparietals large, strongly keeled, imbricate; parietal eye visible; supraoculars in four rows, keeled, imbricate; canthal single, separated from nasal by a tiny scale; scales in frontonasal region keeled, imbricate; internasals six, the two medialmost as long as

.


Table 1 - Sexual variation in scutellation and measurements (mm) of Stenocercus sinesaccus sp. nov. Range followed by mean \pm standard deviation is given for quantitative characters if applicable.

\begin{tabular}{lcc}
\hline CHARACTER & Males $(\mathrm{N}=3)$ & Female $(\mathrm{N}=1)$ \\
\hline Scales around midbody & $31-34(32.33 \pm 1.53)$ & 33 \\
Vertebrals & $28-30(28.67 \pm 1.15)$ & 28 \\
Paravertebrals & $32-34(33.33 \pm 1.15)$ & 33 \\
Gulars & $12-14(12.67 \pm 1.15)$ & 14 \\
Supraoculars & 4 & 4 \\
Internasals & 6 & 6 \\
Subdigitals Finger IV & $15-16(15.67 \pm 0.58)$ & 13 \\
Subdigitals Toe IV & $23-24(23.33 \pm 0.58)$ & 25 \\
Tail length/total length & $0.70-0.73(0.72 \pm 0.02)$ & 0.70 \\
Maximum SVL & 73 & 81 \\
\hline
\end{tabular}

wide, and the four lateralmost more than two times longer (longitudinally) than wide; postrostrals four, more than two times wider than high; supralabials four, keeled, more than three times longer than high; infralabials five, keeled, more than three times longer than high; loreals three, keeled; lorilabials in one row, keeled; preocular in contact with canthal; lateral temporals imbricate, keeled; gulars in 12 rows between tympanic openings; all gulars strongly keeled, imbricate, without apical pits or caudal notches; second infralabial in contact with first three sublabials; mental in contact with first pair of infralabials and first pair of postmentals; dorsal and lateral scales of body and neck keeled, imbricate, mucronate; scales around midbody 31 ; vertebrals 28, about 1.5 times larger than adjacent paravertebrals, forming a prominent serrate crest; paravertebrals 34; ventrals keeled, imbricate, mucronate; preauricular fringe absent; neck and body folds absent; limb scales keeled, imbricate; lamellae on Finger IV 15; lamellae on Toe IV 23; tail not compressed laterally; caudals and subcaudals keeled, imbricate; vertebral crest extending less than half length of tail; tail length 2.5 times SVL; posthumeral (Figure 2) and postfemoral pockets absent (Type 1 of Cadle 1991); postxiphisternal inscriptional ribs I-III in contact medially (pattern 6A of Torres-Carvajal, 2004); caudal fracture planes absent.

Color in preservative of holotype - Dorsum of head and body light brown; subocular and loreal regions whitish cream; dark brown bar extending anterodorsally from commissure of mouth to eye; gular and ventral surfaces golden brown; ventrolateral edges (approximately two scales wide) of body between hind and fore limbs iridescent pink; tail with alternating dark and light brown rings.

Natural History - Data on natural history was not available for the specimens examined. Scrocchi et al. (1985) reported that the brown background color of $S$. caducus provides camouflage against the substrate (e.g., leaf litter, tree trunks). This is probably the case for Stenocercus sinesaccus sp. nov., which also has a brown background color. In addition, Scrocchi et al. (1985) described a very interesting defense behavior in $S$. caducus. They observed individuals of this species that remained immobile after adopting a position in which the pink ventrolateral edges of the body between fore and hind limbs were displayed. Moreover, as part of this behavior, the snout was moved downwards 

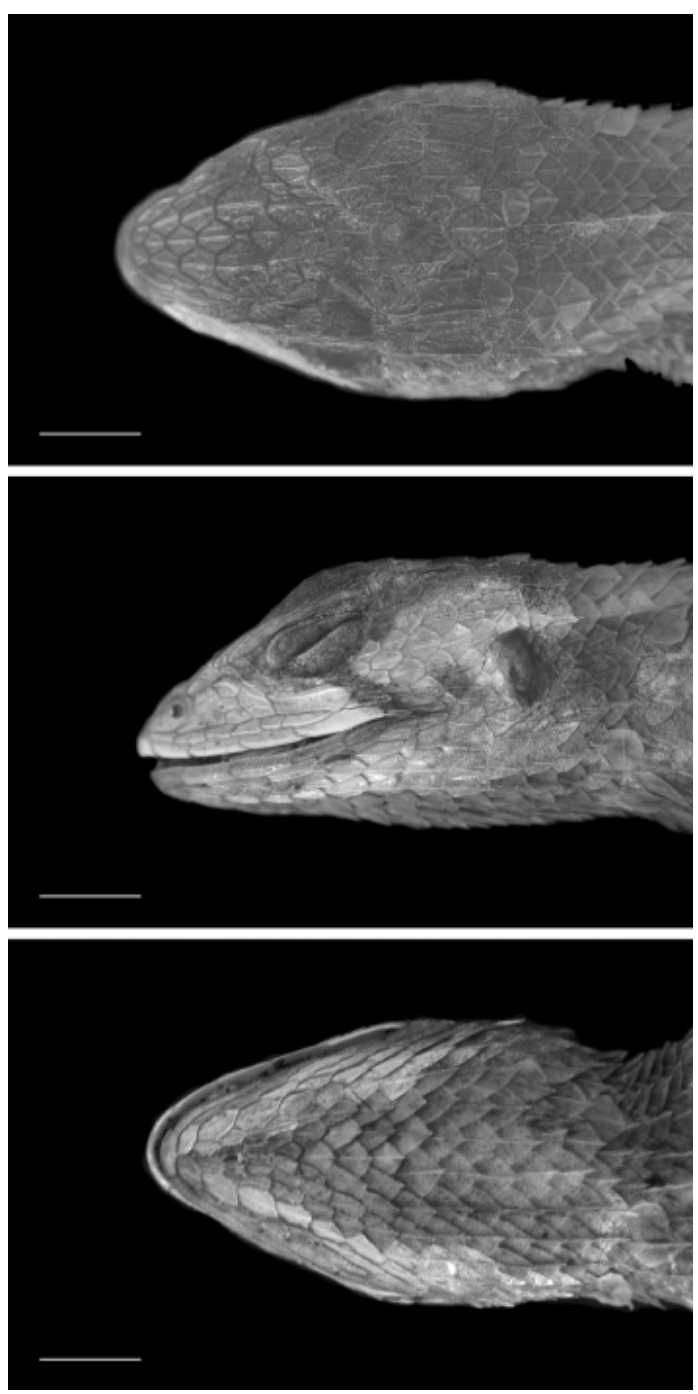

Figure 3 - Dorsal (top), lateral (middle), and ventral (bottom) views of the head of Stenocercus sinesaccus sp. nov. Holotype, BMNH 1903.3.26.7, male. Scale bars $=5 \mathrm{~mm}$.

giving the lizard the appearance of being dead (Scrocchi et al. 1985). Given that the ventrolateral edges of the body between fore and hind limbs in S. sinesaccus also are pink, it is very likely that this species adopts the same defense behavior as $S$. caducus.
Distribution - Stenocercus sinesaccus sp. nov. is known only from its type locality, Chapada dos Guimarães, $15^{\circ} 26^{\prime}$ S, 5545’ W, 690 m, Mato Grosso, Brazil (Figure 4). This city lies within the Cerrado (savanna) Biome and is part of the Chapada dos Guimarães National Park.

Etymology - The epithet sinesaccus is derived from the Latin words sine, meaning "without" and saccus, meaning "pocket, bag." This name refers to the absence of mite pockets in $S$. sinesaccus, a trait that distinguishes this species from the morphologically similar $S$. prionotus and S. caducus (Figure 2).

\section{Discussion}

Presence of Stenocercus caducus in Brazil remains to be confirmed. Cope (1887) provided the first record of $S$. caducus for Brazil based upon examination of specimens collected by $\mathrm{H}$. $\mathrm{H}$. Smith at or near the "village of Chapada, 30 miles northeast of Cuiabá” (Cope 1887, Vanzolini 1953). This locality seems to correspond to Chapada dos Guimarães, the type locality of the new species herein described. I have examined these specimens and they correspond to the new species described in this paper, which means that Cope (1887) misidentified the two specimens from Mato Grosso as $S$. caducus, a species described 25 years earlier by himself (Cope 1862). This is not surprising because, in his description of $S$. caducus, Cope (1862) did not mention the presence of a deep posthumeral mite pocket, which has later been recognized as a very important taxonomic character (Cadle 2001). I have confirmed the presence of a deep posthumeral mite pocket in the holotype of $S$. caducus (USNM 5852). This structure is absent in the specimens from Mato Grosso examined in this study. In addition, Stenocercus sinesaccus sp. nov. has relatively larger scales than $S$. caducus, which is reflected in differences in scale count numbers between these two species (Table 2). The second and only other voucherbased record of $S$. caducus for Mato Grosso was 


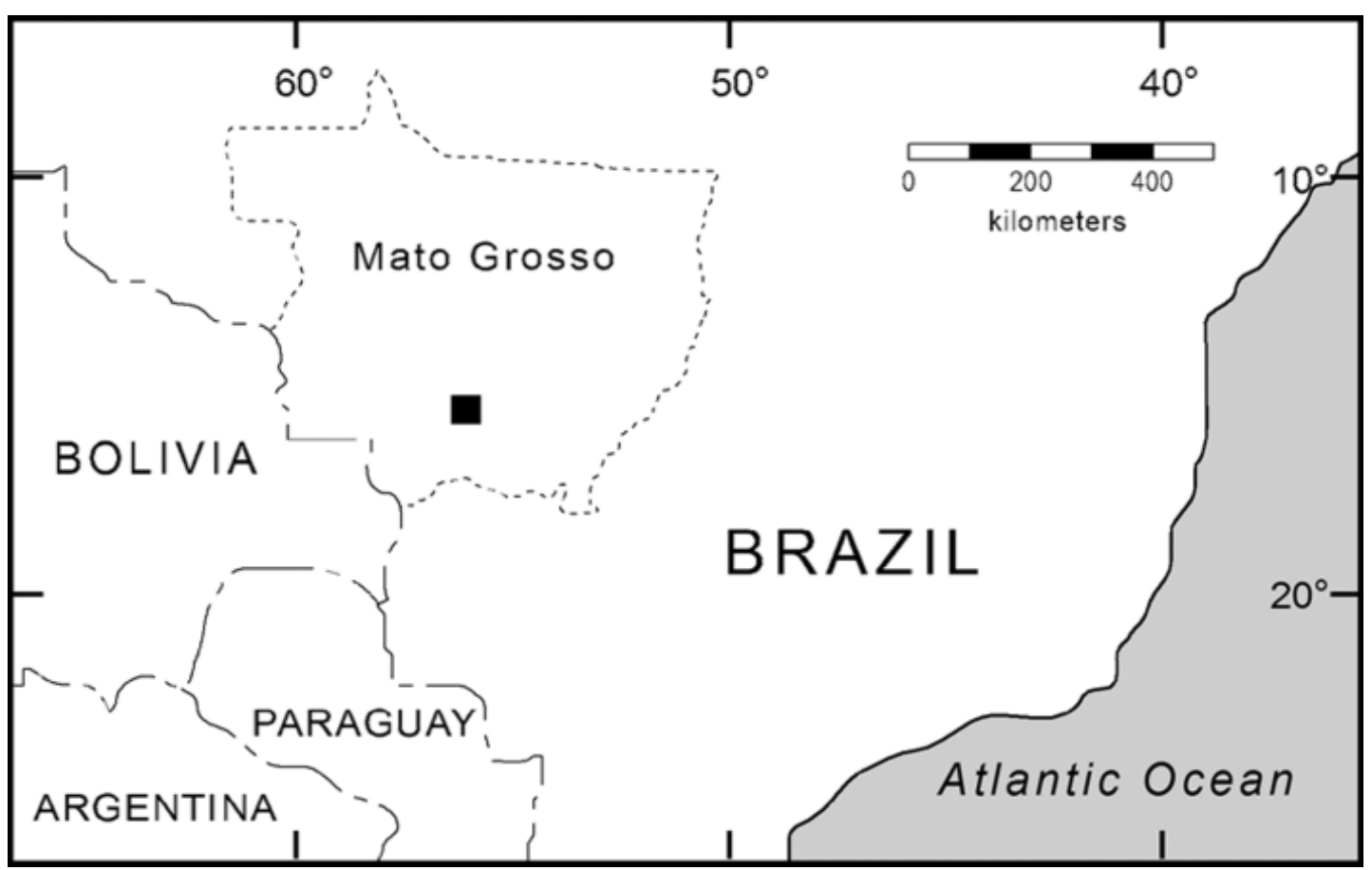

Figure 4 - Distribution of Stenocercus sinesaccus sp. nov.

provided by Boulenger (1903) based on specimens collected in the Percy Sladen expedition to central Brazil by M. A. Robert. These specimens include the holotype and one of the paratypes of Stenocercus sinesaccus sp. nov. Later reports of S. caducus from Brazil (e.g., Peters and DonosoBarros 1970, Cei 1993) do not refer to any voucher specimens and are probably based on Cope's (1887) and Boulenger's (1903) accounts. Etheridge (1966) and Gallardo (1959) did not report $S$. caducus from Brazil as suggested by Scrocchi et al. (1985). Therefore, the presence of $S$. caducus in Brazil has not been verified, although its occurrence in this country seems likely because it has been reported in Bolivia near the Brazilian border (Cadle 2001).

Cei $(1986,1993)$ reported $S$. pectinatus from Brazil without reference to voucher specimens. A recent study on the distribution of S. pectinatus suggests that these records are mistaken (Avila 1999); therefore, I question the presence of this species in Brazil in the absence of voucher specimens. Accordingly, I currently recognize seven species of Stenocercus from Brazil $-S$. azureus, S. caducus, $S$. dumerilii, S. fimbriatus, $S$. roseiventris, $S$. sinesaccus, and $S$. tricristatus (Table 2) - although more new species remain to be described (e.g., Ávila-Pires et al. 1999).

Key to the species of Stenocercus of Brazil

1. Ventral scales smooth, caudal scales with strongly projected mucrons ..... S. roseiventris Ventral scales keeled, caudal scales not mucronate

2. Posthumeral mite pocket present ................. 3

Posthumeral mite pocket absent ................... 4

3. Axillary flap covering posthumeral mite pocket, dorsal scales strongly keeled, no enlarged supraoculars S. caducus No axillary flap, dorsal scales weekly keeled, one longitudinal row of enlarged supraoculars

S. fimbriatus 
A new species of Stenocercus (Squamata, Iguania) from central-western Brazil

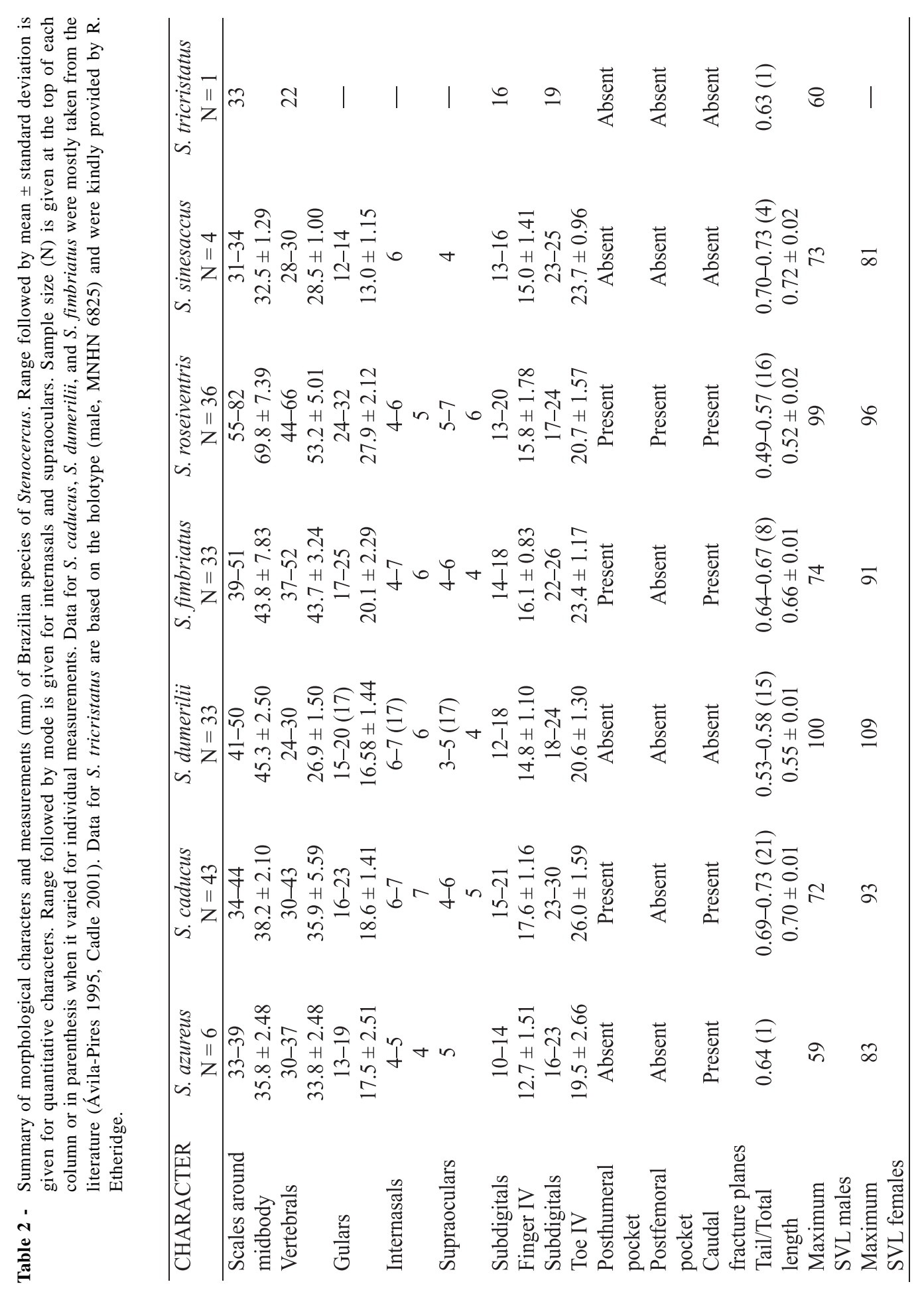

Phyllomedusa - 4(2), December 2005 
4. Post-supraciliary enlarged

Post-supraciliary not enlarged 6

5. Enlarged post-supraciliary distinctly pointed, two enlarged scales above ear opening

S. dumerilii

Enlarged post-supraciliary blunt, no enlarged scales above ear opening. S. tricristatus

6. Two distinct dorsolateral white or cream stripes, tail length less than twice snout-vent length, mental in contact with sublabials

S. azureus

No dorsolateral white stripes, tail length more than twice snout-vent length, mental not in contact with sublabials Stenocercus sinesaccus sp. nov.

\section{Acknowledgements}

I thank T. Ávila-Pires (MPEG), J. Campbell (UTA), K. de Queiroz (USNM), L. Ford and D. Frost (AMNH), N. Gilmore (ANSP), J. Hanken (MCZ), M. Kearney (FMNH), S. Kretzschmar (FML), C. McCarthy (BMNH), and L. Trueb (KU) for the loan of specimens; J. Rosado for his assistance during my visit to MCZ and for sending photographs; A. Campbell for assistance with x-ray photographs; R. Etheridge and L. Trueb for critical review of the manuscript. Special thanks to R. Etheridge for providing important data. This research was partially funded by an MCZ Ernst Mayr Travel Grant.

\section{References}

Avila, L. J. 1999. Geographic distribution. Stenocercus pectinatus. Herpetological Review 30: 111-112.

Ávila-Pires, T. C. S. 1995. Lizards of Brazilian Amazonia (Reptilia: Squamata). Nationaal Natuurhistorisch Museum Zoologische Verhandelingen 299: 1-706.

Ávila-Pires, T. C. S., M. Martins, and O. Marques. 1999. O gênero Stenocercus (Reptilia: Squamata: Tropiduridae) em Minas Gerais, Brasil. V Congreso Latinoamericano de Herpetología. Museo Nacional de Historia Natural, Montevideo, Uruguay, Publicación Extra 50: 32

Boulenger, G. A. 1903. List of the batrachians and reptiles collected by M. A. Robert at Chapadá, Matto Grosso, and presented by Mrs. Percy Sladen to the British Museum (Percy Sladen Expedition to Central Brazil). Proceedings of the Zoological Society of London 2: 69-70.

Cadle, J. E. 1991. Systematics of lizards of the genus Stenocercus (Iguania: Tropiduridae) from northern Perú: new species and comments on relationships and distribution patterns. Proceedings of the Academy of Natural Sciences of Philadelphia 143: 1-96.

Cadle, J. E. 1998. New species of lizards, genus Stenocercus (Iguania: Tropiduridae), from western Ecuador and Peru. Bulletin of the Museum of Comparative Zoology 155: 257-297.

Cadle, J. E. 2001. A new species of lizard related to Stenocercus caducus (Cope) (Squamata: Iguanidae) from Peru and Bolivia, with a key to the "Ophryoessoides Group". Bulletin of the Museum of Comparative Zoology 157: 183-222.

Cei, J. M. 1986. Reptiles del centro, centro-oeste y sur de la Argentina. Herpetofauna de las zonas áridas y semiáridas. Torino, Italy. Museo Regionale di Scienze Naturali, Monografia IV. 527 pp.

Cei, J. M. 1993. Reptiles del noroeste, nordeste y este de la Argentina. Herpetofauna de las selvas subtropicales, puna y pampas. Torino, Italy. Museo Regionale di Scienze Naturali, Monografia XIV. 949 pp.

Cope, E. D. 1862. Contributions to neotropical saurology. Proceedings of the Academy of Natural Sciences of Philadelphia 14: 176-188.

Cope, E. D. 1887. Synopsis of the Batrachia and Reptilia obtained by H. H. Smith in the province of Mato Grosso, Brazil. Proceedings of the American Philosophical Society 25: 44-60.

Duméril, A. M. 1851. Catalogue Méthodique de la Collection des Reptiles. Paris, France. Muséum National d'Histoire Naturelle. 128 pp.

Duméril, A. M. and G. Bibron. 1837. Erpétologie Générale ou Histoire Naturelle Complète des Reptiles. Vol. 4. Paris, France. Librairie Encyclopedique de Roret. 571 pp.

Etheridge, R. 1966. The systematic relationships of West Indian and South American lizards referred to the iguanid genus Leiocephalus. Copeia 1966: 79-91.

Fritts, T. H. 1972. New species of lizards of the genus Stenocercus from Perú (Sauria: Iguanidae). Occasional Papers of the University of Kansas Museum of Natural History 10: 1-21.

Frost, D. R., R. Etheridge, D. Janies, and T. A. Titus. 2001. Total evidence, sequence alignment, evolution of polychrotid lizards, and a reclassification of the Iguania (Squamata: Iguania). American Museum Novitates 3343: 1-38. 
Gallardo, J. M. 1959. Sobre un Iguanidae del noroeste argentino Leiocephalus caducus Cope. Acta Zoologica Lilloana 17: 485-497.

Lehr, E. 2002. Amphibien Und Reptilien in Peru. Die Herpetofauna Entlang Des 10. Breitengrades Von Peru: Arterfassung, Taxonomie, Ökologische Bemerkungen Und Biogeographische Beziehungen. Münster, Germany. Natur und Tier-Verlag. 208 pp.

Macey, J. R., A. Larson, N. B. Ananjeva, and T. J. Papenfuss. 1997. Evolutionary shifts in three major structural features of the mitochondrial genome among iguanian lizards. Journal of Molecular Evolution 44: 660-674.

Peters, J. A. and R. Donoso-Barros. 1970. Catalogue of the Neotropical Squamata: Part II. Lizards and amphisbaenians. United States National Museum Bulletin 297: 1-293.

Schulte, J. A., II, J. P Valladares, and A. Larson. 2003. Phylogenetic relationships within Iguanidae inferred using molecular and morphological data and a phylogenetic taxonomy of iguanian lizards. Herpetologica 59: 399-419.
Scrocchi, G., A.Marcus, and Lavilla, E. 1985. Ophryoessoides caducus (Cope). Revue Francaise d'Aquariologie 2/85: 292.

Torres-Carvajal, O. 2000. Ecuadorian lizards of the genus Stenocercus (Squamata: Tropiduridae). Scientific Papers of the University of Kansas Museum of Natural History 15: 1-38.

Torres-Carvajal, O. 2004. The abdominal skeleton of tropidurid lizards (Squamata: Tropiduridae). Herpetologica 60: 75-83.

Torres-Carvajal, O. 2005a. A new species of iguanian lizard (Stenocercus) from the western lowlands of southern Ecuador and northern Peru. Herpetologica 61: 78-85.

Torres-Carvajal, O. 2005b. New species of Stenocercus (Squamata: Iguania) from the Andes of central Peru with a redescription of S. variabilis. Journal of Herpetology 39: 471-477.

Vanzolini, P. E. 1953. On the type locality of some Brazilian reptiles and amphibians collected by $\mathrm{H}$. $\mathrm{H}$. Smith and described by E. D. Cope. Copeia 1953: 124-125.

\section{Appendix I - Specimens Examined}

Stenocercus azureus.-BRAZIL: PARANÁ: Ponta Grossa, AMNH 131858; Rio GRANDE DO Sul: Cruz Alta, MCZ 133257; No sPeCIFIC LOCALITY: BMNH 85.2.3.3. URUGUAY: Cerro Largo, USNM 65535; SORIANO: BMNH 74.10.9.5; No SPECIFIC LOCALITY: AMNH 17013.

Stenocercus caducus.-BOLIVIA: BeNI: 6 km W Casarabe, 230 m, AMNH 143054; Соснавамва: 6.5 km N Chipiri, KU 133890; Chuquisaca: Sud Cinti, trail from Rinconada Bufete to El Palmer, UTA 39102; SANTA CRUZ: Buena Vista, AMNH 37813-14, BMNH 1927.8.1.163, FMNH 16165, 21486, 21511, MCZ 20625, 29023; Chiquitos, Canton-El Cerro, Finca Dos Milanos, UTA 38046; Velasco, El Refugio, UTA 38047; Velasco, Inselburgs near Florida, UTA 38048; near Santiago, FMNH 195983; TARIJA: Villa Montes, KU 136354-55; No SPECIFIC LOCALITY: BMNH 1946.8.29.76. PARAGUAY: Chaco, USNM 69874; Alto Para-
GUAY: Parque Nacional Defensores del Chaco, 15 km N Tribu Nueva, Cerro Leon, USNM 347911; Primavera, BMNH 1960.1.2.62; АмАмBAY: Parque Nacional Cerro Cora, ca. 32 km WSW Pedro Juan Caballero, USNM 34201920; CaAguazu: Yhu, MCZ 34214-5; CAnindeyu: ca. 35 km NE Curuguaty, Colonia Chupa Pou, AMNH 143306-11; Central: Asunción, BMNH 94.3.14.4, FMNH 9496; Colonia Nueva Italia, FMNH 42281; Itapua: Parabel, KU 290963; Paraguari: Parque Nacional Ybycui, $1 \mathrm{~km} \mathrm{E}$ Administración, USNM 342021; Parque Nacional Ybycui, Mirador, USNM 342022-23; No SPECIFIC LOCALITY: USNM 5852 (holotype). NO LOCALITY DATA: SDSU 1689-90.

Stenocercus dumerilii.-BRAZIL: PARÁ: km 23 road to Maracanã, MPEG 6032, 6036, 60823, 6085, 6252, 6254, 7322-3, 7325, 7327-8; Igarape-Assu, BMNH 1904.7.26.5; Santa Rosa, road to Vigia, MPEG 7376, 7386. 
Stenocercus fimbriatus.-PERU: LORETO: Iquitos, AMNH 56780, 56786-7, 56793; Iquitos region, Río Itaya, AMNH 56778-9, 56783-4; Mishuana, KU 212628; Ucayali: Alto Purus, Igarape Champuia, Alto Curanja, MCZ 61226; Contamana, AMNH 56803; E of Contamana, on trail to Contaya, AMNH 56781-2; Pampa Hermosa, mouth of Rio Cushabatay, AMNH 56788, 56790-2, 56794-6, 56801-2; Utoquinia region, AMNH 56789, 56799, 56800; San Martín: La Pinita, Río Mixiollo, AMNH 567978; NO LOCALITY DATA: FMNH 56070.

Stenocercus roseiventris.-ARGENTINA: Salta: Aguas Blancas, FML 1092; Angosto del Río Pescado, finca Yakúlica, FML 3644; Baritú, FML 1727; Finca Abra Grande, quebrada Tartagal, FML 1584; Macueta-Acambuco, FML 848; Río Blanco, ca. 6 km from Orán, FML 591; Jusuy: Parque Nacional Calilegua, FML 7640;
BOLIVIA: СоснавамBA: Yungas de Cochabamba, USNM 94094; No specific locality: AMNH 6766. PERU: Cusco: km 164 PaucartamboAtalaya road, USNM 346178; Cashiriari-3, S of Camisea River, USNM 538336, 538338;

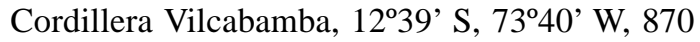
m, AMNH 101384-5; Misión Coribeni, 24 km ENE Rosalina, KU 134156; Pagoreni on Camisea River, USNM 538339; San Martin-3, ca. $5 \mathrm{~km} \mathrm{~N}$ of the Camisea River, USNM 538337; Huanuco: Rio Llullapichis, 4-5 km upstream from Rio Pachitea, Finca Panguana, KU 172194-5; Loreto: Monte Alegre, Río Pachitea, AMNH 57200; MAdRE DE Dios: Cusco Amazónico, 15 km E Puerto Maldonado, KU 194939, 204987, 207769, 207770, 209967, 214964, 214966-7, 214969, 220188; Puno: 1 km W Yanahuaya, USNM 299525; No SPECIFIC Department: Chanchamayo, 4000-6000 ft, AMNH 56309, 57167, 57170. 